\title{
EFEK PAPARAN ASAP PENGOLAHAN IKAN DENGAN CARA DI PANGGANG TERHADAP INDEKS TROMBOSIT PADA PEDAGANG MAKANAN DI KOTA PALANGKA RAYA
}

\section{Effect of Smoke Exposure to Fish Processing by Grilling on Thrombocyte Indices in Grilled Fish Seller in Palangka Raya}

\author{
1*Dwi Purbayanti \& ${ }^{2}$ Syahrida Dian Ardhany \\ ${ }^{1}$ Department of Medical Laboratory Technology, Universitas Muhammadiyah Palangkaraya, Jl. RTA. Milono Km. 1,5, Palangka Raya, \\ Indonesia \\ ${ }^{2}$ Department of Pharmacy, Universitas Muhammadiyah Palangkaraya, Jl. RTA. Milono Km. 1,5, Palangka Raya, Indonesia
}

*e-mail : dwipurbayanti@gmail.com

\begin{abstract}
ABSTRAK
Proses pengolahan ikan dengan cara dipanggang dapat menghasilkan emisi yang berkontribusi terhadap polutan di udara, yang mengandung senyawa kimia toksik yang dapat memberikan efek jangka pendek dan panjang bagi kesehatan manusia. Beberapa penelitian melaporkan hubungan yang positif antara jumlah paparan polusi udara dengan indeks trombosit. Penelitian ini dilakukan pada subjek penjual ikan panggang di Kota Palangka Raya sebanyak 73 orang, dan sebagai kontrol adalah penjual makanan yang tidak menjual makanan panggang sebanyak 33 orang.Pengukuran indeks trombosit (MPV, PDW, P-LCR dan PCT) menggunakan alat Hematology Analyzers KX300.Hasil menunjukkan perbedaan yang signifikan pada indeks trombosit untuk parameter MPV, PDW dan P-LCR pada kelompok terpapar dibandingkan kontrol, dengan nilai pada kelompok terpapar lebih tinggi dibandingkan kontrol.Dan untuk parameter PCT, tidak terdapat perbedaan yang signifikan meskipun nilai terpapar lebih tinggi dibandingkan kontrol. Kandungan senyawa kimia berbahaya yang ada dalam asap hasil pengolahan ikan dengan cara di panggang, dapat meningkatkan aktivasi trombosit yang dapat mengarah ke peradangan/inflamasi.
\end{abstract}

Kata kunci : Indeks Trombosit, MPV, Palangka Raya, PDW, P-LCR, PCT, Asap Ikan Panggang

\section{ABSTRACT}

Fish processing by grilled can produce emissions that contribute to pollutants in the air, which contain toxic chemical compounds that can provide short-term and long-term effects on human health. Some studies report a positive relationship between the amount of exposure to air pollution and the platelet index. The research was conducted on the subject of grilled fish sellers in Palangka Raya (73 respondents) and the control was fish food seller without sell grilled fish (33 respondents).Measurement of platelet indices (MPV, PDW, P-LCR and PCT) used KX300 Hematology Analyzers. The results showed a significant difference in platelet indices for MPV, PDW and P-LCR parameters in the exposed group compared to controls, with values in the exposed group higher than controlsand for PCT parameters, there was no significant difference even though the exposure value was higher than the control. The content of harmful chemical compounds present in the smoke of processing grilled fish, can increase platelet activation that can lead to inflammation.

Keyword: Grilled fish seller, MPV, Palangka Raya, PDW, Platelet, P-LCR, PCT

\section{PENDAHULUAN}

Ikan panggang merupakan salah satu olahan ikan yang sangat digemari oleh masyarakat dan telah menjadi kuliner khas dari Indonesia terutama di Palangka Raya, sehingga bisnis kuliner ini menjadi sangat diminati oleh para pelaku usaha dan telah manjamur dimana-mana. Hidangan ini diolah dengan cara memanggang ikan di atas arang atau bara api, yang bertujuan untuk menambah cita rasa, warna dan aroma agar menjadi lebih nikmat.
Proses pengolahan ikan dengan cara dipanggang menggunakan arang dapat menghasilkan emisi seperti partikulat (PM), karbonmonoksida (CO), polisiklik aromatik hidrokarbon (PAH), nitrogen oksida (NOx), sulfur dioksida $\left(\mathrm{SO}_{2}\right)$, senyawa organik mudah menguap (VOC), logam berat (flouraide, arsenik, timbal, merkuri dan selenium) dan senyawa kimia toksik lainnya yang dapat memberikan efek jangka pendek dan jangka panjang bagi kesehatan manusia (WHO, 2010). 
Asap yang dihasilkan oleh proses pemanggangan ikan ini dapat memberikan kontribusi terhadap polutan di udara.Polutan tersebut diketahui dapat menyebabkan efek kesehatan yang merugikan dengan berinteraksi dengan molekul yang penting bagi proses biokimia atau fisiologis tubuh manusia (Mistry et al., 2016).

Paparan polusi udara, terutama partikulat (PM), telah dikaitkan dengan peningkatan risiko morbiditas dan mortalitas penyakit kardiovaskular (Hoek et al., 2013). PM menginduksi produksi spesies oksigen reaktif (ROS). Peningkatan ROS mengaktifkan jalur pro-inflamasi dan pro-trombotik, menghasilkan disfungsi endotel, peningkatan koagulasi darah dan perkembangan aterosklerosis, yang merupakan kontributor perkembangan penyakit kardiovaskular (Zhang et al., 2018).

Trombosit dan indeks trombositselain berperan dalam hemostasis dan trombosis, juga dapat digunakan sebagai penanda inflamasi (Oncel et al., 2015). Indeks trombosit adalah biomarker aktivasi trombosit yang berkaitan dengan morfologi dan kinetika proliferasi trombosit (Budak, et al., 2016). Indeks trombosit terdiri dari mean platelet volume (MPV),platelet distribution width (PDW), platelet large cell ratio (P-LCR), dan plateletcrit (PCT).

MPV menunjukkan ukuran rata-rata trombosit dan aktiviasi trombosit, digunakan sebagai indikator peradangan dan thrombosis (Gasparyan et al., 2011). PDW merupakan ukuran anisositosis trombosit dandihitung sebagai koefisien variasi dalam volume trombosit rata-rata. Nilai PDW tinggi menunjukkan bahwa perubahan volume trombosit rata-rata lebih dari biasanya (Bain et al., 2017). Nilai PDW merupakan penanda spesifik terhadap aktivasi trombosit (Vagdatli et al., 2010). P-LCR adalah rasio trombosit yang besar. Ini juga telah digunakan untuk memantau aktivitas trombosit (Budak et al., 2016) dan mengevaluasi kondisi yang terkait dengan jumlah trombosit yang abnormal (Barman et al., 2014). PCT adalah persentase volume trombosit dalam darah, berkaitan dengan jumlah dan ukuran trombosit.PCT merupakan analog dari hematokrit (HCT) yang merupakan indikator massa sel darah merah (Budak et al., 2016).
Studi pada hewan menunjukkan bahwa paparan akut PM dapat dengan cepat menginduksi aktivasi trombosit (Becerra et al., 2016). Studi pada manusia telah dilaporkan adanya hubungan paparan akut/jangka pendek pada PM dengan peningkatan kadar penanda koagulasi (Chuang et al., 2007). Studi pada masyarakat kota Wuhan dan Zhuhai China, dilaporkan terdapat hubungan positif antara konsentrasi PAH pada urin dengan indeks trombosit (Yuan et al., 2019). Karabacak, et al., melaporkan terjadi peningkatan yang signifikan pada MPV dan jumlah trombosit pada pasien keracunan $\mathrm{CO}$ (Karabacak et al., 2014).

Masih terbatasnya informasi terkait efek terhadap indeks trombosit akibat paparan senyawa kimia berbahaya yang berasal dari polusi udara terutama asap hasil proses pengolahan makanan di panggang. Kami melakukan studi terhadap individu yang sering terpapar asap pengolahan ikan dengan cara di panggang di atas bara api, dengan melakukan pengukuran indeks trombosit MPV, PDW, P-LCR dan PCT menggunakan alat analisis hematologi.

\section{METODE PENELITIAN}

\section{Sampling Individu}

Diperoleh sebanyak 73 orang pedagang ikan panggang yang berjualan di wilayah kecamatan Pahandut dan Jekan Raya kota Palangka Raya, berusia 20-50 tahun, bekerja sebagai pemanggang ikan selama $>5$ tahun, dalam kondisi sehat, tidak memiliki riwayat penyakit kronis, tidak merokok, tidak menstruasi (bagi perempuan) dan secara sukarela bersedia untuk mengikuti penelitian ini sebagai kelompok yang terpapar. Sedangkan untuk kelompok kontrol dipilih pedagang makanan yang tidak berjualan makanan yang dipanggang, dan diperoleh sebanyak 33 orang.

\section{Kaji Etik dan Persetujuan Pengambilan Tindakan.}

Penelitian ini telah lolos kaji etik melalui Komite Etik Penelitian Kesehatan Fakultas Kedokteran Universitas Lambung Mangkurat Banjarmasin Indonesia berdasarkan nomor 821/KEPK-FK-UNLAM/EC/VII/2018. Sebelum dilakukan pengambilan sampel darah, responden diminta untuk mengisi informed consent sebagai bukti 
bahwa responden bersedia dan tanpa paksaan untuk diikutkan sebagai sampel penelitian.

\section{Sampling Darah.}

Sampel darah diambil pada kondisi aseptik dari fossa cubiti (vena) sebanyak $3 \mathrm{~mL}$.Kemudian darah dimasukkan ke dalam tabung vakum tutup lavender yang berisi antikoagulan EDTA.

\section{Pengukuran Indeks Trombosit.}

Sampel darah kemudian dibawa ke Laboratorium Klinik Fakultas Ilmu Kesehatan Universitas Muhammadiyah Palangkaraya untuk dilakukan pemeriksaan parameter hematologi, termasuk indeks trombosit (MPV, PDW, P-LCR dan PCT) menggunakan instrument hematology analyzers Sysmex KX 300.

\section{Analisis Statistik.}

Hasil dinyatakan dalam rerata \pm SD.Nilai rerata kedua kelompok dibandingkan dengam t-tes tidak berpasangan.Perbedaan dianggap signifikan jika $\mathrm{P}<$ 0.05 pada $95 \%$ CI.

\section{HASIL DAN PEMBAHASAN}

Individu yang dijadikan subjek pada penelitian ini berjumlah 106 pedagang makanan di kota Palangka Raya yang berjualan di sekitar kawasan kecamatan Pahandut dan Jekan Raya. Sebanyak 73 orang sebagai kelompok terpapar, merupakan pedagang makanan yang dipanggang yang mana setiap hari terpapar asap hasil pengolahan ikan dengan cara di panggang. Sedangkan 33 orang sebagai kelompok kontrol, yang merupakan pedagang makanan namun tidak melakukan/berjualan makanan yang.

TABEL 1. Karakteristik Subjek Kelompok Terpapar dan Kontrol

\begin{tabular}{lcc}
\hline \multicolumn{1}{c}{ Parameter } & $\begin{array}{c}\text { Terpapar } \\
(\mathbf{n = 7 3 )}\end{array}$ & $\begin{array}{c}\text { Kontrol } \\
(\mathbf{n = 3 3 )}\end{array}$ \\
\hline Jenis Kelamin (L / P) & $52 / 21$ & $18 / 15$ \\
Umur (Rerata \pm SD) & $33,5 \pm 10,2$ & $33.4 \pm 8,8$ \\
Lama Berjualan (Rerata \pm SD) & $6,4 \pm 4,5$ & $4,7 \pm 2,6$ \\
\hline
\end{tabular}

Karakteristik subjek pada tabel 1, untuk kelompok terpapar sebanyak 52 orang laki-laki dan 21 orang perempuan dengan rerata umur 33,5 \pm 10,2 tahun, dan rerata lama berjualan makanan di panggang adalah 6,4 \pm 4,5 tahun. Sedangkan untuk kelompok kontrol sebanyak 18 orang laki-laki dan 15 orang perempuan dengan rerata umur $33,4 \pm 8,8$ tahun, dan rerata lama berjualan adalah 4,7 $\pm 2,6$ tahun.

TABEL 2. Hasil Pengukuran Indeks Trombosit Pada Kelompok Terpapar dan Kontrol

\begin{tabular}{lccc}
\hline Indeks Trombosit & $\begin{array}{c}\text { Terpapar } \\
(\mathbf{n}=\mathbf{7 3}) \\
\text { Rerata } \pm \text { SD }\end{array}$ & $\begin{array}{c}\text { Kontrol } \\
(\mathbf{n}=\mathbf{3 3}) \\
\text { Rerata } \pm \text { SD }\end{array}$ & $\boldsymbol{P}$-value \\
\hline PDW (fL) & $11,7 \pm 1,2$ & $11,1 \pm 1,1$ & 0,005 \\
MPV (fL) & $9,9 \pm 0,7$ & $9,5 \pm 0,5$ & 0,031 \\
P-LCR (\%) & $23,7 \pm 5,5$ & $21,3 \pm 4,5$ & 0,035 \\
PCT (\%) & $0,32 \pm 0,07$ & $0,31 \pm 0,07$ & 0,067 \\
\hline
\end{tabular}

Hasil analisis hematologi untuk parameter indeks trombosit pada tabel 2.Terdapat perbedaan yang signifikan pada parameter PDW antara kelompok terpapar dan kelompok kontrol dengan nilai PDW11,7 $\pm 1,2 \mathrm{fL}$ pada terpapar dan 11,1 $\pm 1,1 \mathrm{fL}$ pada kontrol dengan $P$-value $<0,05$. Perbedaan yang signifikan juga terlihat pada parameter MPV, dengan nilai 9,9 $\pm 0,7 \mathrm{fL}$ pada kelompok terpapar dan 9,5 \pm $0,5 \mathrm{fL}$ pada kelompok kontrol dengan $P$-value $<0,05$. Parameter P-LCR juga memiliki perbedaan yang signifikan antara kelompok terpapar dan kontrol, dengan nilai $23,7 \pm 5,5 \%$ pada kelompok terpapar dan $21,3 \pm 4,5 \%$ pada kelompok kontrol dengan $P$-value < 0,05 . Sedangkan untuk parameter PCT meskipun nilai pada kelompok terpapar lebih tinggi dibandingkan kelompok kontrol, namun perbedaannya tidak signifikan dengan nilai $0,32 \pm 0,07 \%$ pada kelompok terpapar dan $0,31 \pm 0,07 \%$ pada kelompok kontrol dengan $P$-value $>0,05$.

Trombosit memainkan peran penting dalam proses peradangan. Beberapa penelitian melaporkan adanya hubunganperubahan indeks trombosit dan aktivasi sistem koagulasi, terhadap infeksi berat, trauma, inflamasi sistemik, dan penyakit trombotik (Thachil, 2015).

Hasil menunjukkan bahwa indeks trombosit pada kelompok terpapar memiliki nilai yang lebih tinggi dibandingkan kontrol untuk parameter MPV, PDW, P-LCR dan PCT meskipun yang memiliki perbedaan signifikan adalah untuk parameter MPV, PDW dan P-LCR.Kandungan senyawa kimia berbahaya seperti PAH dalam asap hasil proses pengolahan ikan dengan cara di panggang turut berkontribusi terhadap peningkatan nilai indeks trombosit. Hasil ini sejalan dengan penelitian Yuan et 
al. (2019), terdapat hubungan yang positif antara paparan senyawa kimia berbahaya $\mathrm{PAH}$ yang terkandung dalam polusi udara, dengan indeks trombosit.Paparan polusi udara telah diyakini memberikan kontribusi terhadap peradangan sistemik/stres oksidatif, gangguan sistem fibrinolitik, aktivasi pembekuan darah, dan perubahan sistem saraf otonom pada manusia muda yang sehat (Chuang et al., 2007).

Paparan partikulat matter (PM) juga telah dilaporkan, dimana terjadi peningkatan jumlah trombosit pada paparan jangka panjang (Zhang et al., 2018). Polutan dan partikulat di udara dapat memasuki paru dan mengaktifkan refleks neural paru dan peradangan lokal untuk mengubah sistem saraf otonom, menginduksi peradangan sistemik / stres oksidatif, dan meningkatkan koagulabilitas darah (Pope et al., 2004). Indeks trombosit merupakan penanda untuk aktivasi trombosit (Budak et al., 2016). Studi pada hewan menunjukkan bahwa paparan akut PM dapat dengan cepat menginduksi aktivasi trombosit (Becerra et al., 2016).

Tabel 2 menunjukkan terdapat perbedaan yang signifikan pada nilai MPV, dimana MPV pada kelompok terpapar lebih tinggi dibandingkan kontrol. Peningkatan MPV berhubungan dengan peningkatan diameter trombosit, yang dapat digunakan sebagai penanda peningkatan produksi dan aktivasi trombosit (Budak et al., 2016). Yuan et al. (2018) melaporkan terjadi peningkatan nilai MPV yang sebanding dengan jumlah paparan PAH pada individu yang terpapar polusi udara.Hal yang sama juga dilaporkan Karabacak et al. (2014) yang menunjukkan peningkatan MPV pada pasien dengan keracunan karbonmonoksida (CO). Peningkatan nilai MPV dapat menunjukkan bahwa pasien dengan keracunan $\mathrm{CO}$ memiliki risiko lebih tinggi mengalami komplikasi tromboemboli dan kardiovaskular karena peningkatan aktivasi trombosit (Karabacak et al., 2014). Peningkatan MPV ini menunjukkan bahwa respon inflamasi sistemik pada tubuh dapat dipicu oleh peningkatan paparan PAH. Trombosit berukuran lebih besar memiliki reaktivitas yang lebih tinggi dan mengandung lebih banyak granula, yang menginduksi peningkatan pembentukan tromboksan A2 dan kemudian agregat trombosit menjadi inflamasi (Hu et al., 2018).

Perbedaan yang signifikan juga terlihat pada parameter PDW, dimana nilai PDW lebih tinggi padakelompok terpapar dibandingkan kontrol.PDW adalah indikator variabilitas ukuran trombosit, berubah karena aktivasi trombosit, dan meningkat dengan adanya anisositosis trombosit. MPV dan PDW banyak digunakan sebagai biomarker klinis untuk mencerminkan ukuran dan aktivitas trombosit dalam kaitannya dengan trombosis dan peradangan. Tingkat PDW yang lebih rendah mewakili volume trombosit homogen (Budak et al., 2016).

P-LCR biasanya berkorelasi dengan MPV, tetapi lebih sensitif terhadap peningkatan ukuran trombosit. Hasil penelitian ini menunjukkan nilai $\mathrm{P}$ LCR pada kelompok terpapar lebih tinggi dibandingkan kelompok kontrol, dan terdapat perbedaan yang signifikan diantara kedua kelompok tersebut.Peningkatan P-LCR biasanya terjadi bersamaan dengan peningkatan jumlah trombosit yang baru diproduksi, yang merupakan tipe trombosit terbesar. Peningkatan P-LCR dapat menunjukkan adanya agregat trombosit, mikroeritrosit, dan trombosit raksasa(Yilmaz \& Yilmaz, 2016).

PCT juga meningkat pada subjek terpapar dibandingkan kontrol, namun perbedaan tersebut tidak signifikan. PCT dapat digunakan sebagai biomarker yang sensitif dan spesifik untuk menentukan penyakit aktif terutama pada pasien dengan hs-CRP lebih rendah dari $10 \mathrm{mg} / \mathrm{L}$. Perubahan PCT telah dilaporkan pada sejumlah kecil penyakit inflamasi dan pasien kanker (Tang et al., 2015). Nilai PCT yang rendah menunjukkan abnormalitas trombosit yang diakibatkan oleh tidak adanya respon sumsum tulang terhadap permintaan perifer untuk trombosit (Budak et al., 2016).

\section{KESIMPULAN}

Hasil menunjukkan bahwa indeks trombosit (MPV, PDW, P-LCR dan PCT) pada kelompok terpapar memiliki nilai yang lebih tinggi dibandingkan kontrol.Kandungan senyawa kimia berbahaya yang ada dalam asap hasil pengolahan ikan dengan cara di 
panggang, dapat meningkatkan aktivasi trombosit yang dapat mengarah ke peradangan/inflamasi.

\section{DAFTAR PUSTAKA}

Bain, Barbara J., Imelda Bates, and Mike A Laffan. 2017. Dacie and Lewis Practical Haematology (Twelfth Edition). Edited by MD Emeritus S. MITCHELL LEWIS, BSc and FIBMS FRCPath, DCP. Twelfth Ed. Elsevier B.V.

Barman, T., Kalahasthi, R. \& Rajmohan, H.R., 2014. Effects of lead exposure o. The status of platelet indices in workers involved in a lead-acid battery manufacturing plant. Journal of Exposure Science and Environmental Epidemiology, 24(6), pp.629-633.

Becerra, A.Z. et al., 2016. Increases in ambient particulate matter air pollution, acute changes in platelet function, and effect modification by aspirin and omega-3 fatty acids: A panel study. Journal of Toxicology and Environmental Health, Part A, 79(6), pp.287-298. Available at:

http://www.tandfonline.com/doi/full/10.1080/1 5287394.2016.1157539.

Budak, Y.U., Polat, M. \& Huysal, K., 2016. The use of platelet indices, plateletcrit, mean platelet volume and platelet distribution width in emergency non-traumatic abdominal surgery: A systematic review. Biochemia Medica, 26(2), pp.178-193.

Chuang, K.J. et al., 2007. The effect of urban air pollution on inflammation, oxidative stress, coagulation, and autonomic dysfunction in young adults. American Journal of Respiratory and Critical Care Medicine, 176(4), pp.370$376 . \quad$ Available at: http://www.atsjournals.org/doi/abs/10.1164/rcc m.200611-1627OC.

Gasparyan, A.Y. et al., 2011. Mean platelet volume: a link between thrombosis and inflammation? Current pharmaceutical design, 17(1), pp.47$58 . \quad$ Available at: http://www.ncbi.nlm.nih.gov/pubmed/2124739
Hoek, G. et al., 2013. Long-term air pollution exposure and cardio- respiratory mortality: a review. Environmental health : a global access science source, 12(1), p.43. Available at: http://www.ncbi.nlm.nih.gov/pubmed/2371437 0\%0Ahttp://www.pubmedcentral.nih.gov/articl erender.fcgi?artid=PMC3679821.

$\mathrm{Hu}$, C. et al., 2018. Association of polycyclic aromatic hydrocarbons exposure with atherosclerotic cardiovascular disease risk: A role of mean platelet volume or club cell secretory protein. Environmental Pollution, 233, pp.45-53. Available at: https://doi.org/10.1016/j.envpol.2017.10.042.

Karabacak, M. et al., 2014. Mean platelet volume in patients with carbon monoxide poisoning. Angiology, 65(3), pp.252-256.

Mistry, H. et al., 2016. Study of red blood cell count, hemoglobin concentration, and platelets in petrol pump workers of Surat city. National Journal of Physiology, Pharmacy and Pharmacology, 6(2), p.167. Available at: http://www.njppp.com.

Oncel, M. et al., 2015. Evaluation of Platelet Indices in Lung Cancer Patients. Asian Pacific Journal of Cancer Prevention, 16(17), pp.7599-7602. Available at: http://koreascience.or.kr/journal/view.jsp?kj=P OCPA9\&py $=2015 \& v n c=v 16 n 17 \& s p=7599$.

Pope, C.A. et al., 2004. Ambient particulate air pollution, heart rate variability, and blood markers of inflammation in a panel of elderly subjects. Environmental Health Perspectives, 112(3), pp.339-345.

Tang, J. et al., 2015. Plateletcrit: A sensitive biomarker for evaluating disease activity in Crohn's disease with low hs-CRP. Journal of Digestive Diseases, 16(3), pp.118-124.

Thachil, J., 2015. Platelets in Inflammatory Disorders: A Pathophysiological and Clinical Perspective. Seminars in Thrombosis and Hemostasis, 41(6), pp.572-581.

Vagdatli, E. et al., 2010. Platelet distribution width: A simple, practical and specific marker of 
activation of coagulation. Hippokratia, 14(1), pp.28-32.

WHO. 2010. "Selected Pollutants." WHO Guidelines for Indoor Air Quality: Selected Pollutants, 484. doi:10.1186/2041-1480-2-S2-I1.

Yilmaz, T. \& Yilmaz, A., 2016. Relationship between altered platelet morphological parameters and retinopathy in patients with type 2 diabetes mellitus. Journal of Ophthalmology, 2016(Mi).

Yuan, C. et al., 2019. Dose-response relationships between polycyclic aromatic hydrocarbons exposure and platelet indices. Environmental Pollution, 245, pp.183-198. Available at: https://doi.org/10.1016/j.envpol.2018.10.127.

Zhang, Z. et al., 2018. Long-term exposure to ambient particulate matter (PM2.5) is associated with platelet counts in adults. Environmental Pollution, 240, pp.432-439. 